\title{
Usage of Online Education in the Field of Mathematics for Hearing Impaired and Deaf Students
}

\author{
Dmitry M. Chirkov ${ }^{1 *}$, Mikhail D. Konstantinov ${ }^{1}$, Artyom N. Semakin ${ }^{1}$, Galina P. \\ Yemgusheva ${ }^{1}$, and Mikhail V. Mozgovoy ${ }^{1}$ \\ ${ }^{1}$ Bauman Moscow State Technical University, 2nd Baumanskaya str., 5/1, 105005, Moscow, Russia
}

\begin{abstract}
The article is devoted to problems of usage of online education in the inclusive education process in BMSTU. Russian and foreign experience in the field of mass open online courses in the system of higher education is briefly described. Information on foreign platform Coursera, Russian online courses construction platform Stepik and the National Open Education platform is given. The experience of Ural Federal University in development of two first online courses for people with disabilities is shown. The article describes educational features and specific needs of students with impaired hearing in the system of higher education on the base of BMSTU's years-long experience in work with groups of students of that type. The model of inclusive higher education in Bauman university is briefly described and explained. Main stages of development and approbation of online course on elementary mathematics knowledge actualization for hearing-impaired and deaf students on the first year of education in BMSTU are revealed. Practical recommendations for online courses' authors on materials selection, preparation, video recording and other stages of online course creation are given. Prospects of the developed course usage and plans for further activities of the university in that field are shown.
\end{abstract}

\section{Introduction}

In recent years online education has become one of the leading trends in many countries. According to EdMarket Research [1], in Russia the part of distant educa-tion in higher education (in relation to students amount) will have grown up to $9 \%$ by year 2021 . A bright example of successful online education development is the online magister program organized by Moscow Institute of Physics and Technology (MIPT) in cooperation with Russian Presidential Academy of National Economy and Public Administration under the President of the Russian Federation (RANEPA), which allows to receive the master's degree in economics and get RANEPA diploma in case of successful program acquisition during online education process.

* Corresponding author: chirkovdm@bmstu.ru 
In a number of countries a blended learning has become normal in higher educa-tion, and it is a combination of traditional classroom-based and distance education. As an example the results of research conducted by Allen I. E. and Seaman [2] can be used: about $42 \%$ of professionals in the field of USA higher education, among whom the survey for Online Report Card: Tracking Online Education in the United States research was conducted, mentioned blended education as a more promising then the distance one; about $77 \%$ of world ranking American universities lecturers consider online education to be equal (and in some cases more preferable) alternative to the traditional education.

One of the largest international projects in the sphere of mass online education is Coursera [3], which has been founded in 2011 in Stanford University. The project has collaborations with universities which publish and run courses in different fields. Stu-dent passes the courses, communicate with peers, passes tests and exams directly on Coursera website. By the January of 2020 Coursera joins 40 million users and more than 3600 courses and specializations provided by more than 190 educational organ-izations all over the world, and by Russian universities too. The access to the course requires to be payed for (the price is $15 \$$ and higher), but free access to the course is also possible in case of sending a motivation letter and its acceptance by the plat-form.

This country also has a great number of aggregation platforms and online courses constructors. One of the most popular platforms for information technologies study-ing is «Stepik» [4]. This educational platform and online courses constructor has been founded in 2013. Its specific feature is that the authors develop adaptive education algorithms, freely collaborate with MOOC (mass open online courses) authors and help in organization of academic competitions and retraining programs. The majority of the courses are free for students and devoted to information technologies but are not limited by this field. The platform has gained a high popularity among students interested in programming languages online studying and other spheres of IT. They also cooperate with leading universities and IT corporations in Russian Federation.

In recent years Russian universities also have become active participants of online courses market. Some universities use them only for their own students (usually as SMOK - small private online courses), while the others open them for everybody and even give certificates by the end of course acquisition.

Finally in 2015 The National Open Education Platform was launched in order to increase accessibility and education quality in the country. The platform has become a result of cooperation of the following leading universities: Lomonosov Moscow State University, SPbPU, SPbU, NUST "MISiS", HSE University, MIPT, UrFU and ITMO University [5]. All courses placed on the platform can be accessed free of charge and have no formal requirements to basic education level. Those who want the passed course to be accepted for their bachelor or specialist degree have an op-portunity to receive certificate. Certificate can be received if the student has over-come all control activities in the online course and has passed personal identification under controlled conditions. Online education fields of the highest priority (on the base of the platform's statistics) are engineering and other technical sciences [6].

However, in spite of a great number of courses (more than 450 in January 2020) and students using them, there are not many universities thinking of accessability of that education format for disabled people. It was only the December of 2019 when the platform has opened two first courses taking into account specific educational requirements from disabled people. The course has been prepared by Ural Federal University and devoted to the following topic: "Basics of personal development (for disabled people)" and "Organism resourced development (for disabled people)" [7,8]. Accessibility of courses for disabled people is provided by the following means: 
- For hearing impaired and deaf students lections are presented as simple graphic schemes and short sentences. All video lections are provided with subtitles [8].

- For visually impaired and blind students lections are presented as audio tracks [8].

- Moreover, specialists on different defects, psychologists, sign language interpreters and others were involved in the course development.

One of the courses' interface is shown on figure 1.

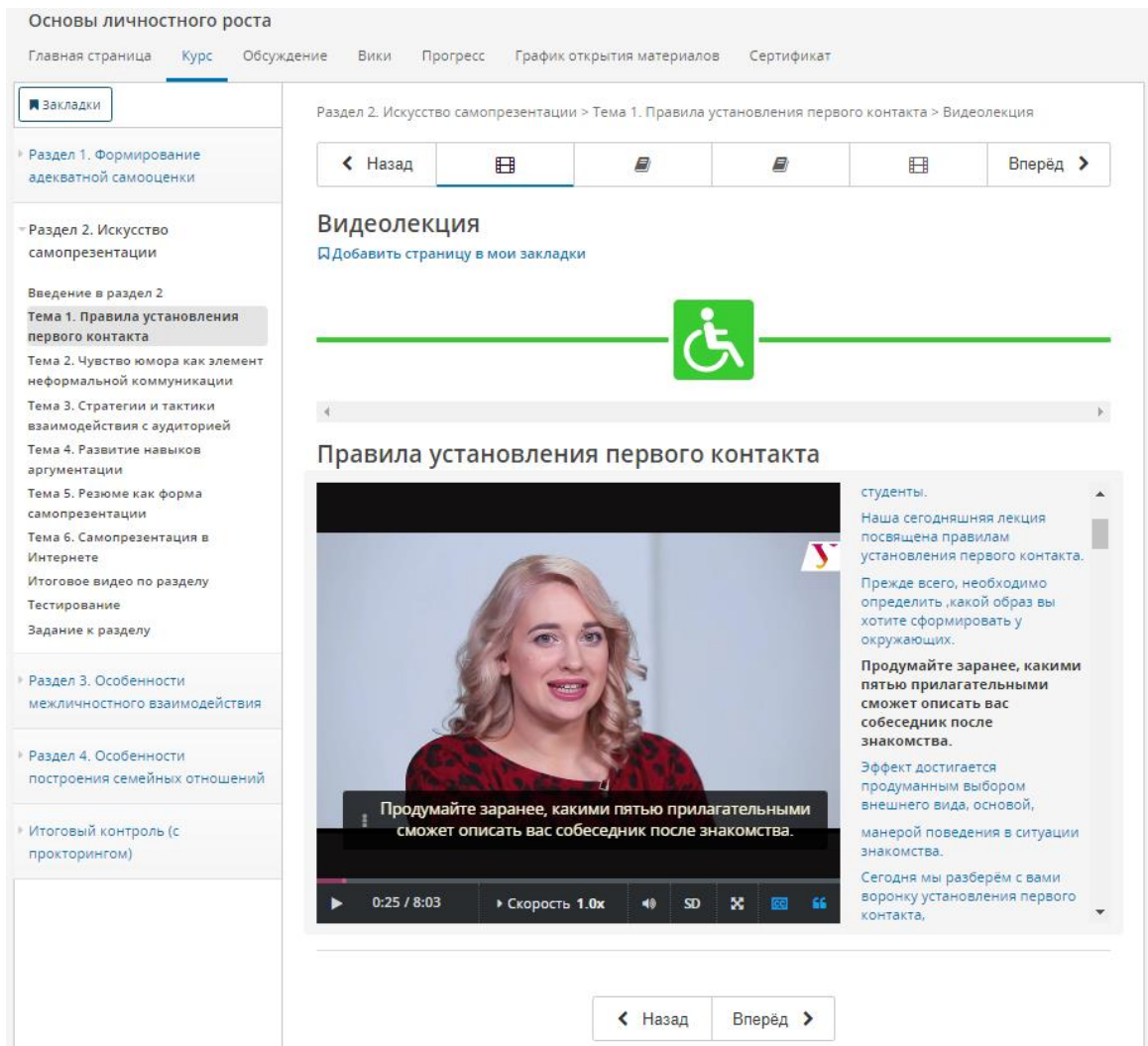

Fig. 1. The «Basics of personal development» course developed by UrFU.

Table 1. Contains of Figure 1.

\begin{tabular}{|c|c|}
\hline Phrase in Russian & English equivalent \\
\hline Основы личностного роста & Basics of personal development \\
\hline Главная страница & Main page \\
\hline Курс & Course \\
\hline Обсуждение & Discussion \\
\hline Вики & Wiki \\
\hline Прогресс & Progress \\
\hline График открытия материалов & Materials accessibility time schedule \\
\hline Сертификат & Certificate \\
\hline Закладки & Bookmarks \\
\hline $\begin{array}{c}\text { Раздел 1. Формирование адекватной } \\
\text { самооценки }\end{array}$ & Unit 1. Building of a reasonable self-esteem \\
\hline Раздел 2. Искусство самопрезентации & Unit 2. Art of self-presentation \\
\hline Введение в раздел 2 & Unit 2 Introduction \\
\hline
\end{tabular}


Table 1. (Continued) Contains of Figure 1.

\begin{tabular}{|c|c|}
\hline Phrase in Russian & English equivalent \\
\hline $\begin{array}{c}\text { Тема 1. Правила установления первого } \\
\text { контакта }\end{array}$ & Theme 1. Rules of first contact establishment \\
\hline $\begin{array}{c}\text { Тема 2. Чувство юмора как элемент } \\
\text { неформальной коммуникации }\end{array}$ & $\begin{array}{l}\text { Theme 2. Sense of humor as an element of } \\
\text { informal communication }\end{array}$ \\
\hline $\begin{array}{l}\text { Тема 3. Стратегии и тактики } \\
\text { взаимодействия с аудиторией }\end{array}$ & $\begin{array}{l}\text { Theme 3. Strategies and tactics at } \\
\text { communication with audience }\end{array}$ \\
\hline Тема 4. Развитие навыков аргументации & Theme 4. Argumentation skills improvement \\
\hline $\begin{array}{c}\text { Тема 5. Резюме как форма } \\
\text { самопрезентации }\end{array}$ & Theme 5. CV as a form of self-presentation \\
\hline Тема 6. Самопрезентация в Интернете & Theme 6. Self-presentation on the Internet \\
\hline Итоговое видео по разделу & Final video on the unit \\
\hline Тестирование & Test \\
\hline Задание к разделу & Task for the unit \\
\hline $\begin{array}{c}\text { Раздел 3. Особенности межличностного } \\
\text { взаимодействия }\end{array}$ & Unit 3. Specifics of interpersonal interaction \\
\hline $\begin{array}{c}\text { Раздел 4. Особенности построения } \\
\text { семейных отношений }\end{array}$ & $\begin{array}{l}\text { Unit 4. Specifics of building of family } \\
\text { relationship }\end{array}$ \\
\hline Итоговый контроль (с практорингом) & Final check (proctored) \\
\hline $\begin{array}{c}\text { Раздел 2. Искусство самопрезентации > } \\
\text { Тема 1. Правила установления первого } \\
\text { контакта > Видеолекция }\end{array}$ & $\begin{array}{l}\text { Unit } 2 . \text { Art of self-representation }>\text { Theme } 1 . \\
\text { Rules of first contact establishment }>\text { Video } \\
\text { lecture }\end{array}$ \\
\hline Назад & Backward \\
\hline Вперёд & Forward \\
\hline Видеолекция & Video lecture \\
\hline Добавить страницу в мои закладки & Add the page to my bookmarks \\
\hline Правила установления первого контакта & Rules of first contact establishment \\
\hline $\begin{array}{c}\text { Продумайте заранее, какими пятью } \\
\text { прилагательными сможет вас описать } \\
\text { собеседник после знакомства }\end{array}$ & $\begin{array}{l}\text { Think ahead which five adjectives might } \\
\text { your companion use after the acquaintance }\end{array}$ \\
\hline $\begin{array}{c}\text { Эффект достигается продуманным } \\
\text { выбором внешнего вида, основой, манерой } \\
\text { поведения в ситуации знакомства }\end{array}$ & $\begin{array}{l}\text { The effect is reached by smart choice of the } \\
\text { appearance and behavior patterns for the } \\
\text { acquaintance }\end{array}$ \\
\hline $\begin{array}{c}\text { Сегодня мы разберем с вами воронку } \\
\text { установления первого контакта }\end{array}$ & $\begin{array}{c}\text { Today we will discuss a funnel of first contact } \\
\text { establishment }\end{array}$ \\
\hline
\end{tabular}

In 2018 BMSTU has started that work: development of a course accessible for hearing impaired students. It's not unexpected, because hearing impaired and deaf students have been studying in this university for more than 85 years, and 25 of these years the process has been supervised by a special department of the university - The head educational, research and methodological center for vocational rehabilitation of persons with disabilities (GUIMC). By the January of 2020 the number of hearing impaired students studying on different fields in inclusive form has reached about 140 people.

Educational process for such groups of students has its own specific features. Dur-ing first two years they study fundamental, social and technical disciplines with addi-tion of special adaptive disciplines in separate groups made of students with different majors; in the beginning of the third year the students are divided into groups belong-ing to the common cohort and further continue educational process with the students who are not hearing impaired and finally are totally integrated into the university's life. The need in such type of educational process organization caused by the fact that hearing impaired and deaf students experience difficulties with high rate of tradi-tional education model which is oriented on contact work in classrooms and direct interaction between lecturers and 
students. Supposedly, integration of mixed educa-tion model elements (here it means online course) into educational process might allow to decrease study load and make the rate of education more comfortable.

Let's consider basic characteristics of hearing impaired students which have been revealed and proved during long-year work of GUIMC specialists in BMSTU. Such students show difficulties in visual thinking, increased time of perception and understanding of educational material, insufficient attention concentration, slow rate of memorizing, difficulties in finding key points of the material and connections in the studied material, difficulties in understanding of the material, difficulties in analysis and synthesis of new results on the base of the material. These problems stimulate education specialists not only to improve existing methods of work, but also search for new ways and means which would help to increase efficiency of educational process for hearing impaired and deaf students [9-16]. One of such means is online education which is actively integrated into education systems in foreign countries [17-22].

The research of mathematical skills of hearing impaired and deaf students per-formed in several countries in recent years, shows that by the end of middle school hearing impaired and deaf students have a lag about 1.5-3 years in the field of math-ematical disciplines comparing to other students [23]. The research has also allowed to reveal that there is no functional dependence between mathematical skills and grade of deafness [24]: about 15\% of deaf students demonstrate the same mathe-matical skills as their peers who are not hearing impaired.

Hearing impaired and deaf students use the same logic and way of analyzing of mathematical problems as students who hear well; mistakes made by them during tests are the same as those made by students who hear well. Slow rate of their educa-tion is due to difficulties in perception of verbal and written language, and, as conse-quence, high concentration on the language component of study [25]. The educa-tional process rate can be increased by the usage of visual patterns of mathematical ideas under study [26-28].

\section{Actualization of knowledge in elementary mathematics with the help of online course}

\subsection{Task setting}

Classes on mathematical disciplines for students with hearing disorders during first years at a university helps to reveal remarkable gaps in their knowledge of the mate-rial and insufficient skills for solving of basic mathematics school tasks. During higher mathematics course it regularly makes it necessary to remind them notions, theorems and formulas from school course, what decreases educational process efficiency.

The online course has been developed in order to make it possible for students to fill in their knowledge gaps in basic mathematics school course and acquire practical skills in elementary mathematics basic tasks solving. The aim of the course is to up-date and regularize basic mathematics ideas which would be used in subsequent learning of mathematical disciplines such as "Mathematical analysis", "Analytical geometry", "Linear algebra" and natural-science disciplines like "Physics".

\subsection{Course preparation and practical recommendations}

The stages of the online course development and support have been organized as follows:

1. Training results planning, defining targets, tasks and online course structure. 
2. Working out mixed education technology, correction of teaching model based on active, practice-oriented education.

3. Development of control activities system and methods of their estimation.

4. Selection of education materials and defining its volume.

5. Development of tasks for self-checking.

6. Presentation development.

7. Director's script development.

8. Additional material selection.

9. Testing video recording.

10. Video recording of the course.

11. Complex examination of the online course.

12. Publication and probing of the course.

13. Support and exploitation of the course.

Let's formulate some recommendations that might be useful for authors of online courses:

1. Information in the course can be divided into the following groups according to the content:

- $\quad$ obligate (its knowledge is evaluated by tests);

- additional (it broadens knowledge in general and allows to build complex advanced trajectory);

- $\quad$ entertaining (increases audience involvement).

2. The obligate information should be given to students during the course, while an external link is enough for the additional part of the information.

3. The information which can potentially be changed and cause the need to be updated is preferable to be given in a text form rather than in a form of a presentation in order to avoid recording of the video again.

4. Text information requires linguistic correctness (editor's or corrector's involvement is preferred), well-designed structure and typographics (placement, decoration, fonts, colors, indents).

5. External educational materials used in the online course shouldn't violate copyrights. It is necessary to pay attention to conditions of usage of fonts, graphical elements, illustrations in lecturer's presentations, videos, sounds and other. It is necessary to name the source of images, and if it is unknown, it is better to avoid its usage and involve a designer into this work.

6. All information on the screen must be visually recognizable while watching it on the smart phone. Extra information should be placed in additional or text materials.

7. It is necessary to follow the lecturer's speech rhythm and gradually show the new information on the screen (it is mostly important for hearing impaired students). If an illustration should appear on the screen, the best moment for it is when the lecturer makes an accent on a key word.

8. Preferably all materials in the video should follow one style (line thickness, colors, fonts and subscriptions), as well as important information should be accented similarly: elements size enlargement, change of color, animation effects and other. Don't make them too different because students should get used to the meaning of each visual effect.

\subsection{Course description}

"Elementary mathematics knowledge actualization" online course consists of 40 classes, each of which is devoted to a separate unit of mathematics school course, and among them 
there are units devoted to algebraic operations on number of pow-ers, operations on polynomials, linear, quadratic, rational and irrational equation solution, solution of equations with the power higher than two, elementary functions characteristics and other.

Each lesson includes theoretical and practical parts. The theoretical part is a presentation which with the help of animation informatively demonstrates studied ideas, formulas, their application and is also followed with a video and lecturer's comments (fig. 2). The duration of the video is 10 minutes. The practical part is a test consisting of 10 tasks aimed at examination of students' memorizing, understanding of the material and ability to apply received knowledge practically (fig. 3).

Students have an opportunity to use subtitles during video lections. We are plan-ning to add a sign language interpretation to each lesson.

Attestation for the discipline has a form of ungraded examination. In order to pass the attestation it is necessary to do all tests for the discipline, and a final test consist-ing of 40 tasks for the whole course material as well.

\section{Решение квадратных уравнений}

๑ Bookmark this page

Лекция 5.2

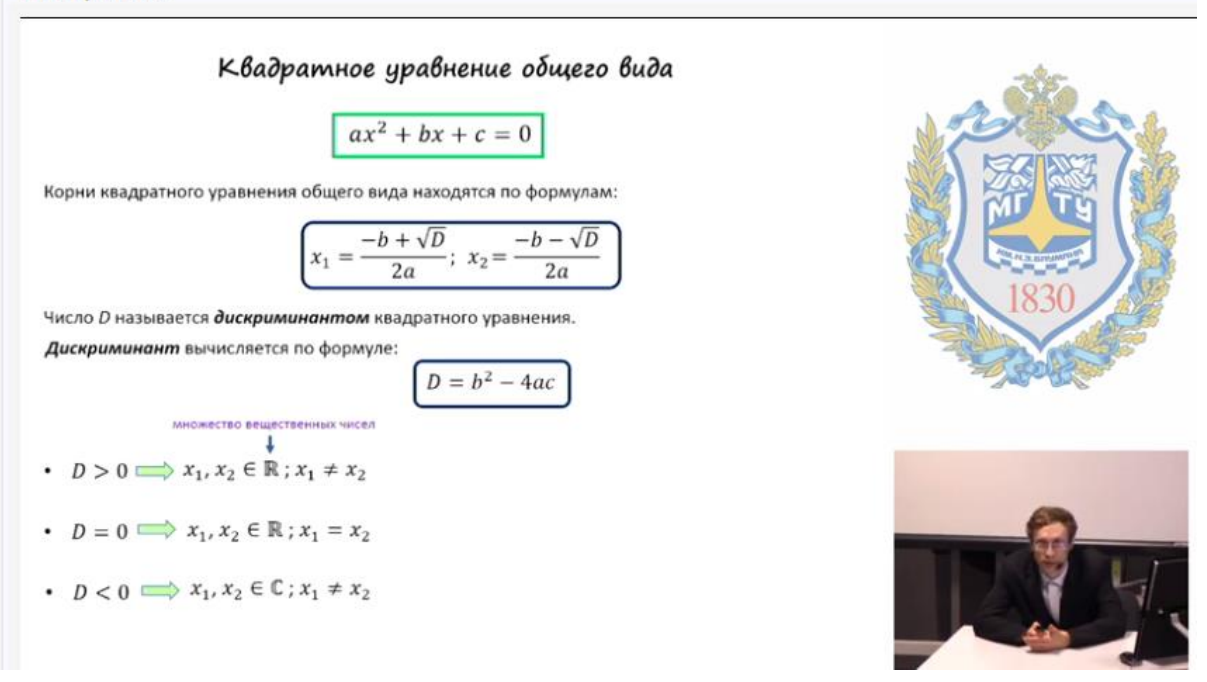

Fig. 2. A screenshot of video lection on solution of quadratic equations.

Table 2. Contains of Figure 2.

\begin{tabular}{|c|c|}
\hline Phrase in Russian & English equivalent \\
\hline Решение квадратных уравнений & Solution of quadratic equations \\
\hline Лекция 5.2 & Lection 5.2 \\
\hline Квадратное уравнение общего вида & General quadratic equation \\
\hline $\begin{array}{c}\text { Корни квадратного уравнения общего вида } \\
\text { находятся по формулам: }\end{array}$ & $\begin{array}{c}\text { Roots of general quadratic equation are } \\
\text { calculated by the following formulas: } \\
\text { Число D называется дискриминантом } \\
\text { квадратного уравнения }\end{array}$ \\
$\begin{array}{c}\text { Number D is a discriminant of the quadratic } \\
\text { equation }\end{array}$ \\
\hline Дискриминант вычисляется по формуле: & Discriminant is calculated by the formula: \\
\hline Множество вещественных чисел & Set of real numbers \\
\hline
\end{tabular}




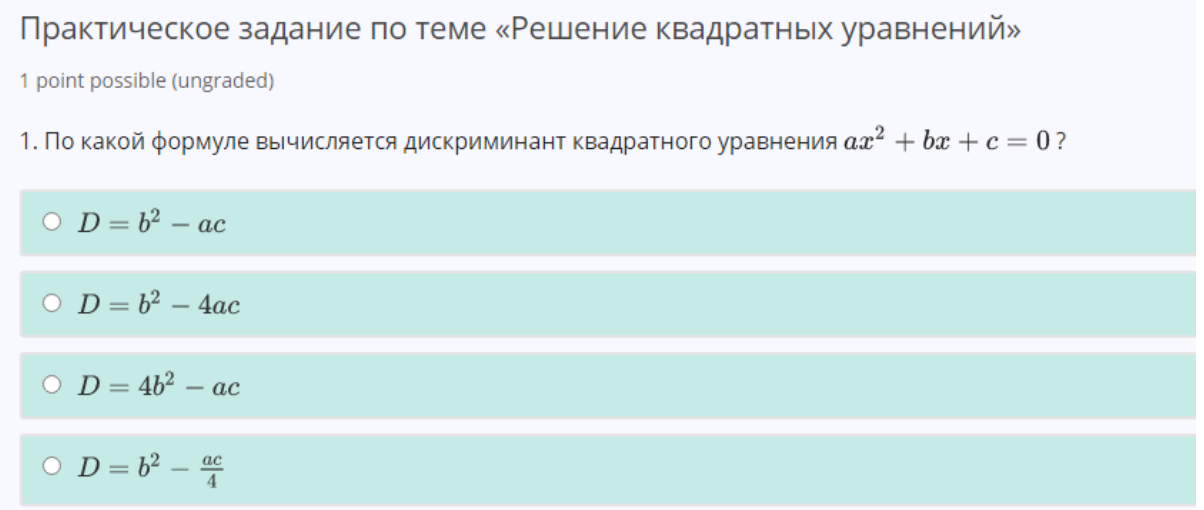

Отправить Вы использовали 0 из 1 попытки

Fig. 3. Example of testing task on solutions to quadratic equation.

Table 3. Contains of Figure 3.

\begin{tabular}{|c|c|}
\hline Phrase in Russian & English equivalent \\
\hline $\begin{array}{c}\text { Практическое задание по теме «Решение } \\
\text { квадратных уравнений» }\end{array}$ & $\begin{array}{c}\text { Practical task on "Solutions to quadratic } \\
\text { equations" }\end{array}$ \\
\hline $\begin{array}{c}\text { 1. По какой формуле вычисляется } \\
\text { дискриминант квадратного уравнения }\end{array}$ & $\begin{array}{l}\text { 1. Which formula is used to solve quadratic } \\
\text { equations }\end{array}$ \\
\hline Вы использовали 0 из 1 попытки & You've used 0 of 1 attempts \\
\hline
\end{tabular}

\subsection{The course workflow}

The course duration is 17 weeks. Week load for a student is 2 academic hours of classroom sessions per week and 2 academic hours of individual work per week. Now we are testing 3 ways of passing the described course:

1. first group of students studies the whole course without assistance: they watch necessary video lections, presentations and do test without tutors (for example, at home);

2. second group watches video lections and studies presentations without any assistance, and does tests in the university with the help of the tutor if needed;

3. third group takes the whole course beginning from video lections till the testing in the classroom with the assistance of the tutor.

Results of the online course passing, and also comparison of the three described approaches are planned to be analyzed and published in a separate work in the future.

During the educational process students receive support and help in overcoming most common problems with the help of "Semantics of technical texts" discipline and tutoring. Within the course of "Semantics of technical texts" several classes are aimed at explanation of right ways of understanding, reading and verbal reproduction of mathematical constructions most common for lectures. As a part of tutoring (technically, individual consultation) every student has an opportunity to individually go through the elements of the discipline which cause difficulties. 


\subsection{The course workflow}

In perspective we are planning to create analogous online courses for each discipline studied by GUIMC students during first years. By nowadays development of the online course for "Mathematical analysis" discipline has already been started. The format of the material explanation within this course is different from the one de-scribed in the unit 3.2 from that side that the lecturer is standing next to a blackboard (fig. 3); it helps students better see face mimics and read information from tutor's lips. An opportunity of addition of subtitles and video image of sign language inter-preter in the right upper corner of the screen in order to increase a number of infor-mation channels and give a student an opportunity to choose the channel to perceive the lecture.

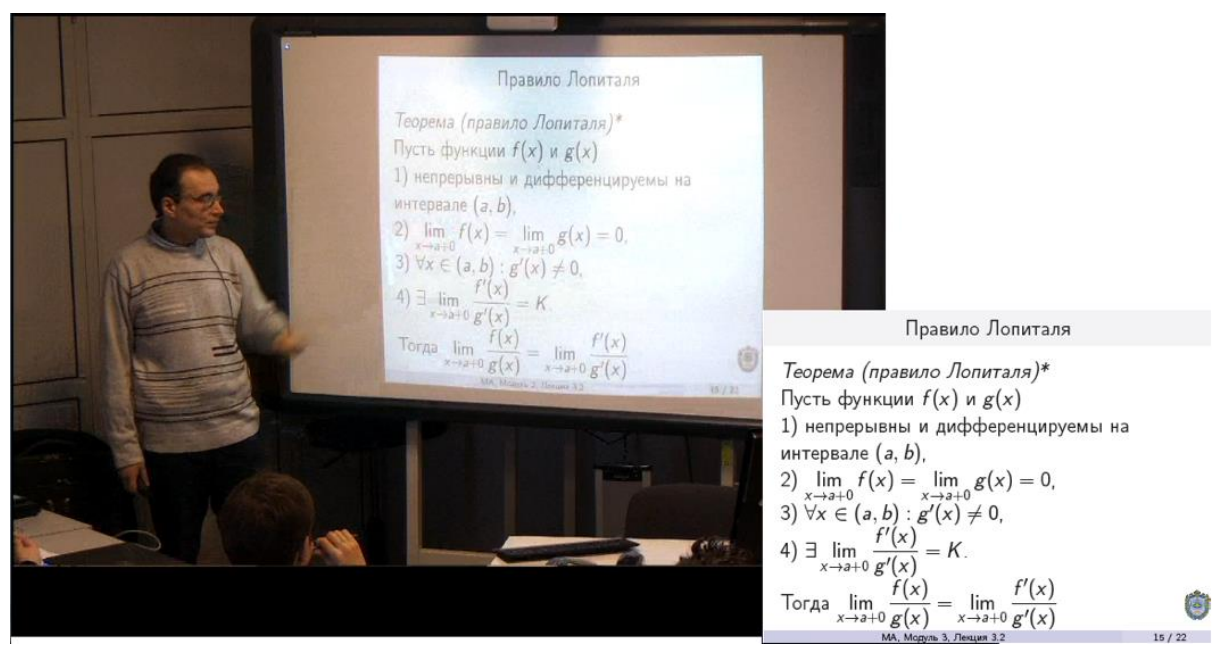

Fig. 4. A screenshot of video lection on L'Hospital rule ("Mathematical analysis" online course).

Table 4. Contains of Figure 4.

\begin{tabular}{|c|c|}
\hline Phrase in Russian & English equivalent \\
\hline Правило Лопиталя & L'Hospital's rule \\
\hline Теорема (правило Лопиталя) & Theorem (L'Hospital's rule) \\
\hline Пусть функции $f(x)$ и $g(x)$ & Let the functions f(x) and g(x) \\
\hline $\begin{array}{c}\text { 1) Непрерывны и дифференцируемы на } \\
\text { интервале }(a, b)\end{array}$ & $\begin{array}{c}\text { 1) be continuous and differentiable on the } \\
\text { interval }(a, b)\end{array}$ \\
\hline
\end{tabular}

\section{Conclusion}

Now "Elementary mathematics knowledge actualization" online course is on the stage of beta-testing: we have organized 3 groups of students each of which is undergoing the course in their own mode (see unit 3.3). In perspective we are planning to provide video lections with sign language interpretation and connect the online course with those courses on higher mathematics which are studied by students during their first terms in the university. The last fact would allow to avoid loss of time during lections and practical classes on explanation of mathematical ideas from a school course and give students an opportunity to receive necessary information from corresponding parts of the online course.

The results of integration of "Elementary mathematics knowledge actualization" online course into educational process are planned to be published in our future works. 


\section{References}

1. Study of the Russian market of online education and educational technologies, https://edumarket.digital/, last accessed 2019/9/12.

2. I.E. Allen, J. Seaman, Changing course: Ten years of tracking online education in the United States, Sloan Consortium, PO Box 1238, Newburyport, MA 01950 (2013).

3. Coursera platform, https://about.coursera.org/, last accessed 2020/1/25.

4. National platform of open education, http://npoed.ru/about, last accessed 2020/1/25.

5. Stepik platform, https://stepik.org/catalog, last accessed 2020/1/25.

6. A.V. Krasnoshekov, M.D. Chapaykina, Analysis of the e-learning system by specialization (on the example of the national portal "open education"), Sovremennaya ekonomika, socialnye vyzovy I finansovye problemy XXI veka. SPbPU press, Saint-Petersburg, pp. 271-278 (2017).

7. Online course "Basics of personal growth (for people with disabilities)", https://openedu.ru/course/urfu/inclus_M1/, last accessed 2020/1/25.

8. Online course "Development of body resources (for people with disabilities)", https://openedu.ru/course/urfu/Inclus_M2/, last accessed 2020/1/25.

9. H. Lang, Higher education for Deaf students: Research priorities in the new millennium, Journal of Deaf Studies and Deaf Education, 7(4), pp. 267-280 (2002).

10. J.K. Fernandes, S.S. Myers, Inclusive deaf studies: Barriers and pathways, Journal of Deaf Studies and Deaf Education, 15(1) pp. 17-29 (2009).

11. H. Knoors, M. Marschark, Teaching deaf learners, Oxford University Press, New York, NY (2014).

12. H. Adler, B. Jacob, K. Kurz, R. Kushalnagar, Undergraduate research in mathematics with deaf and hard-of-hearing students: four perspectives, Journal of Mathematics 7(3), pp. 247-264 (2014).

13. R. Swanwick, M. Marschark, Enhancing education for deaf children: Research into practice and back again, Deafness and Education International, 12(4), pp. 217-235 (2010).

14. C.M. Pagliaro, Mathematics Reform in the Education of Deaf and Hard of Hearing Students, American Annals of the Deaf 143(1), pp. 22-28 (1998).

15. C.M. Pagliaro, Mathematics Preparation and Professional Development of Deaf Education Teachers, American Annals of the Deaf 143(5), pp. 373-379 (1998).

16. M. Berndsen, J. Luckner, Supporting students who are deaf or hard of hearing in general education classrooms: A Washington state case study, Communication Disorders Quarterly, 33(2), pp. 111-118 (2010).

17. S. Burgstahler, Opening doors or slamming them shut? Online learning practices and students with disabilities, Social Inclusion, 3(6), pp. 69-79 (2015).

18. M. Debevc, Z. Stepanovič, A. Holzinger, Development and evaluation of e-learning courses for deaf and hard of hearing students based on the advanced adapted pedagogical (API) index method, Interactive Learning Environments 22(1), pp. 33-50 (2014).

19. G. Nuccetelli, M.T. de Monte, Deaf people education: crossing linguistic borders through e-learning, Monachesi P., Gliozzo A.M., Westerhout E. (eds.) LREC (Language Resources and Evaluation Conference), Valletta, Malta, pp. 24-28. (2010). 
20. E.A. Pizzuto, C.S. Bianchi, D. Capuano, G. Gianfreda, P. Rossini, Language resources and visual communications in a deaf-centered multimodal e-learning environment: Issues to be addressed, Monachesi, P., Gliozzo, A.M., Westerhout, E. (eds.) LREC (Language Resources and Evaluation Conference), Valletta, Malta, pp. 18-23, (2010).

21. A. Sutherland, T. Padden, Videoconferencing for deaf peoples: A case study of on-line education for deaf people, Deafness and Education International 1(2) 114-120 (1999).

22. G. Valentine, T. Skelton, An umbilical cord to the word: The role of the Internet in D/deaf people's information and communication practices, Information, Communication \& Society 12(1), pp. 44-65 (2009).

23. P. Arnold, Deaf children and mathematics, Croatian Review of Rehabilitation Research, 32(1), pp. 65-72 (1996).

24. T. Nunes, C. Moreno, Is hearing impairment a cause of difficulties in learning mathematics?, Donlan, C. (ed.) The development of mathematical skills, pp. 227-254. Hove, UK (1998).

25. R. Swanwick, A. Oddy, T. Roper, Mathematics and deaf children: an exploration of barriers to success, Deafness and Education International, 7(1), pp. 1-21 (2005).

26. T. Nunes, C. Moreno, An intervention program for promoting deaf pupils' achievement in mathematics, Journal of Deaf Studies and Deaf Education, 7(2), pp. 120-133 (2002).

27. J. Vesel, T. Robillard, Teaching Mathematics Vocabulary with an Interactive Signing Math Dictionary, Journal of Research on Technology in Education 45(4), pp. 361-389 (2013).

28. C.M. Pagliaro, E. Ansell, Deaf and Hard of Hearing Students' Problem-Solving Strategies With Signed Arithmetic Story Problems, American Annals of the Deaf 156(5), pp. 438-458 (2012). 